\title{
Merging species? Evidence for hybridization between the eel parasites Anguillicola crassus and A. novaezelandiae (Nematoda, Anguillicolidea)
}

\author{
Daniel S Grabner, Kerstin C Dangel and Bernd Sures
}

\begin{abstract}
Background: The eel parasitic nematodes Anguillicola crassus (originating from Asia) and Anguillicola novaezelandiae (originating from New Zealand) were both introduced to Europe, but occurred in sympatry only in Lake Bracciano in Italy, where they both infected the European eel (Anguilla anguilla). A. novaezelandiae was introduced to the lake in 1975 and disappeared soon after A. crassus was also found there in 1993. We tested the hypothesis if hybridization of the two species might be an explanation for the findings at Lake Bracciano.

Findings: After laboratory infection of one European eel with 10 third stage larvae of each parasite, two living female and 4 male adults of each species were found to co-occur in the swim bladder after 222 days post exposure. In 9 out of 17 eggs, isolated in total from uteri of the two A. novaezelandiae females, alleles were detected by microsatellite analysis that are characteristic for A. crassus, suggesting the hybrid origin of these eggs. In contrast, none of the eggs isolated from A. crassus females possessed alleles different from those found in $A$. crassus adults, but it was revealed that one female can be inseminated by several males.

Conclusion: Our results show that A. crassus and A. novaezelandiae can co-infect a single eel and can mature together in the same swim bladder. We also provide evidence for the possibility of hybridization of $A$. crassus males with A. novaezelandiae females. Therefore, hybridization might be an explanation for the disappearance of A. novaezelandiae from Lake Bracciano.
\end{abstract}

Keywords: Nematode, Anguillicola, Hybridization, Invasive species, Eel parasite, Lago Bracciano

\section{Findings \\ Background}

Nematodes of the genus Anguillicola are eel-specific swim bladder parasites using copepods as intermediate hosts (some Anguillicola spp. were moved to the genus Anguillicoloides according to [1], but recent molecular findings support the original taxonomy [2]). In eel species as final hosts, larval stages are found in the swim bladder wall while adult stages migrate into the swim bladder lumen and feed on the host's blood [3]. The best studied and most abundant species is Anguillicola crassus [4], which was introduced to Europe in the early 1980s through the importation of living eels from Asia [5-8]. The original host of $A$. crassus, the Japanese eel

\footnotetext{
* Correspondence: daniel.grabner@uni-due.de

University of Duisburg-Essen, Aquatic Ecology, Universitaetsstr. 5, Essen 45141, Germany
}

(Anguilla japonica), is well adapted to the parasite and can limit parasite load, for example by massive encapsulation of larval stages $[9,10]$. In contrast, high infection intensities and prevalences were found in European eels (Anguilla anguilla), in which the nematode causes severe damage of the swim bladder wall, a general stress response and mortality of the host [5,11-13]. Therefore, the parasite is expected to threaten European eel populations, especially as the loss of swim bladder function might impair the spawning migration of eels $[12,14]$.

$A$. crassus seems to be the most efficient invader of the genus, but it was not the first to be introduced to Europe. As early as 1975, Short-finned eels (Anguilla australis) from New Zealand infected with Anguillicola novaezelandiae were released into Lake Bracciano in Italy $[15,16]$, where the parasite was able to infect European eels and built a stable population in the lake $[17,18]$. A. novaezelandiae showed high prevalence and 
intensity of infection in European eels, but there are no records of any damage to the swim bladder. To the best of our knowledge, there is no record of A. novaezelandiae being established in waters outside of Lake Bracciano, as this lake is not connected to other waterbodies. In 1993, A. crassus was described for the first time in Lake Bracciano, but no mixed infections of eels with both Anguillicola species were recorded [17].

Subsequently, $A$. crassus became the dominant species in the lake and so far $A$. novaezelandiae was not found any more $[17,19]$. One possible explanation is that $A$. crassus outcompeted and replaced $A$. novaezelandiae, but the two species might have also formed viable hybrids that resemble $A$. crassus morphologically. To assess the latter hypothesis we performed a laboratory infection experiment with subsequent microsatellite analysis, to test i) if $A$. crassus and $A$. novaezelandiae can co-infect the same eel and ii) if they are able to mate and produce hybrid offspring.

\section{Methods}

\section{Infection experiment}

European eels (Anguilla anguilla) were obtained from a commercial fish farm (Albe Fischfarm, Haren/Rütenbrock, Germany), where no cases of Anguillicola crassus infections were ever reported. To confirm the absence of parasites before the experiment, ten eels from the stock were killed, dissected and examined for the presence of parasites.

Anguillicola novaezelandiae collected from Anguilla australis originating from New Zealand and A. crassus collected from $A$. anguilla from lake Müggelsee in Berlin, Germany, were used for the laboratory life cycles. Infective third stage larvae (L3) of A. crassus and A. novaezelandiae were produced by the method of Haenen et al. [20].

For the experiment, one European eel $(40 \mathrm{~cm}, 106 \mathrm{~g}$ ) was infected with $10 \mathrm{~L} 3$ of $A$. crassus and $10 \mathrm{~L} 3$ of $A$. novaezelandiae by administering L3 with a stomach tube (1.5 mm diameter; B. Braun Melsungen AG) as described in [21]. The eel was kept in a $80 \mathrm{~L}$ fish tank at $20^{\circ} \mathrm{C}$ and was fed twice a week for a period of 222 days in order to guarantee the presence of second stage larvae for molecular analyses (for details on the life cycle see [22]). After 222 days post infection (dpi), the eel was killed by decapitation and examined immediately for infection of the swim bladder. Adult parasites were counted and sex was determined. For storage, worms were fixed separately in $70 \%$ ethanol. Anguillicola species were identified morphologically according to [1]. The identification was done without knowledge about the PCR results to avoid bias of the investigator. The infection experiment was conducted in compliance with national and institutional guidelines for the care and use of animals.

\section{Molecular species identification}

Small pieces of the cuticle or the pharynx were cut off from each adult nematode recovered from the eel using sterile technique. Care was taken not to carry-over intestinal content of the worms. DNA was extracted from each sample using a JETQUICK DNA Clean-Up Spin Kit (Genomed) according to manufacturer's instructions. Species-specific primers targeting cox $I$ were designed for both nematode species according to a multiple alignment including cox $I$ sequences from $A$. crassus (GenBank accession no.: EU376921), Anguillicola globiceps (JF805673), Anguillicola papernai (JF805697), Anguillicola australiensis (JF805640), A. novaezelandiae isolate from Tasmania (JF805629), A. novaezelandiae New Zealand isolate (JX868555) from the present study and European eel (HQ600683). Sequences of $A$. crassus specific primers were: crasscox for $5^{\prime}$-CCT TTT GTT AGG TGA TGG GCA A-3', crasscox rev 5'-TAG CGA GAT CAA CAC TTA TAC CAG-3', amplifying a product of $303 \mathrm{bp}$ and for $A$. novaezelandiae (New Zealand isolate): novcox for 5'-ATT GGG TGA CGG CCA GTT ATA-3', novcox rev 5'-ACT TAT ATG CTC CAG AGT AAT AGA ACT A-3', amplifying a product of 404 bp. PCR conditions were optimized and specificity of primers was tested. One $20 \mu \mathrm{l}$ PCR reaction mix contained $4 \mu \mathrm{l}$ of $5 \mathrm{x}$ Crimson Taq buffer (New England Biolabs), $0.2 \mathrm{mM}$ dNTP mix (New England Biolabs), $0.5 \mu \mathrm{M}$ of each primer $0.5 \mathrm{U}$ Crimson Taq (New England Biolabs) and $1 \mu \mathrm{l}$ template DNA. The mix was topped up to $20 \mu \mathrm{l}$ with PCR grade water. PCR was conducted on a TGradient thermocycler (Biometra) with the same program for both primer pairs: $95^{\circ} \mathrm{C}$ for $5 \mathrm{~min}, 35$ cycles of $95^{\circ} \mathrm{C}, 58^{\circ} \mathrm{C}$ and $72^{\circ} \mathrm{C}$ each for $45 \mathrm{~s}$ and a final elongation at $72^{\circ} \mathrm{C}$ for 5 min. PCR products were analysed by standard agarose gel electrophoresis.

\section{Microsatellite analysis}

Microsatellite markers for A. crassus were previously developed by [23]. We tested those seven markers also for A. novaezelandiae and selected two markers (AcrCT04 and AcrCA102) that produced a clearly distinguishable pattern of PCR products for the two species. Each forward primer was labelled at the $5^{\prime}$-end with a fluorescent dye (FAM for AcrCT04 and HEX for AcrCA102).

To analyse the allelic pattern of the adult worms, their DNA was amplified with AcrCT04 and AcrCA102 according to [23]. For characterization of the offspring, ten eggs were dissected from each uterus of female nematodes. Eggs were washed by repeated transfers to drops of clean distilled water on a sterile petri dish. Subsequently, single eggs were placed in reaction tubes, DNA was extracted as described above and amplified with AcrCT04 and AcrCA102. PCR products were 
purified with a JETQUICK PCR Product Purification Spin Kit (Genomed). Products of AcrCT04 and AcrCA102 were pooled and sent for analysis on an Applied Biosystems DNA Analyzer ABI3730 (GATC). Fluorescent peaks were analysed with the Peak Scanner ${ }^{\mathrm{TM}}$ Software v1.0 (Applied Biosystems).

To check for contamination of egg DNA from one nematode species with DNA from the other, all eggs were tested with the cox I-PCR. As cox I is a mitochondrial marker, it should show the identity of the female irrespective of a possible hybrid origin.

\section{Results and discussion}

\section{Infection experiment}

Both primer pairs designed according to the cox $I$ sequence of $A$. crassus and $A$. novaezelandiae were species specific and did not cross react with eel DNA.

In total, 13 adult nematodes were isolated from the swim bladder of the eel, five of which were female and eight male. One of the females was found dead and partly decomposed, therefore this specimen was not used for further analyses. No larval stages (L3 or L4) were detected in the swim bladder wall. The morphological species identification was in accordance with the cox I PCR results. Only the DNA from one female produced a strong band for $A$. novaezelandiae and an additional faint band with the crasscox-primers, indicating contamination of the sample. This problem remained even though new DNA was extracted and tested again twice from this specimen (Table 1 ). As the A. crassusband was faint, we assumed that this specimen was A. novaezelandiae, in compliance with the result of the morphological identification. Two female and four male individuals were identified for each species, which equates to a recovery rate of $60 \%$ (ten third stage larvae from each species were used for infection) for each species with an overall recovery rate of $65 \%$, considering also the dead female. This shows that co-infection of the final host with both species is possible, and might have also occurred in Lake Bracciano.

\section{Microsatellite analysis}

According to the analysis of adult nematodes, allele sizes for marker AcrCT04 ranged from $123 \mathrm{bp}$ - $198 \mathrm{bp}$ for A. crassus, while a single 109 bp allele was characteristic for A. novaezelandiae specimens. AcrCA102 amplified two alleles, one $305 \mathrm{bp}$ and one $325 \mathrm{bp}$. These were detected only in $A$. crassus samples (Table 1). Analysis of microsatellite patterns of the eggs revealed information on parental combinations. Only "A. crassus-alleles" were found in the eggs analysed from the females AC1 and $\mathrm{AC} 2$, showing that species boundaries were not crossed. Characteristic alleles of $A$. crassus males, allowed the identification of the potential father in some cases (Table 2). Apparently, one female was inseminated by several males, giving rise to eggs fertilized by different sperm (e.g. AC3 and AC6 for A. crassus female 1; see also Table 2).

In the offspring of the two A. novaezelandiae females AN1 and AN2, alleles characteristic for A. crassus were detected. In five out of nine eggs from AN1 and in four out of eight eggs from AN2, alleles different from the $109 \mathrm{bp}$ allele were amplified by AcrCT04. In all these individuals, either the 305 bp or the 325 bp " $A$. crassusallele" amplified by AcrCA102 was found as well, strongly indicating hybrid origin of these eggs, attributable to at least three different $A$. crassus males. Contamination was excluded in these cases by cox I-PCR that detected only $A$. novaezelandiae (maternal) mitochondrial DNA in the hybrids (Table 2).

In some cases, no PCR product was obtained from single eggs (Table 2). Most likely, DNA-extraction was unsuccessful, because eggs were lost during collection and washing as they easily stick in pipette tips and other plastics. For egg no. 3 and egg no. 7 of $A$. crassus female no. 2, more than two alleles were detected by marker AcrCT04, which revealed contamination of the sample

Table 1 Results of morphological and molecular examination of adult nematodes

\begin{tabular}{|c|c|c|c|c|c|c|c|c|c|c|c|c|c|}
\hline \multirow[t]{2}{*}{ No. } & \multicolumn{6}{|c|}{ A. crassus } & \multicolumn{6}{|c|}{ A. novaezelandiae } & \multirow{2}{*}{$\begin{array}{l}\text { dead } q \\
-\end{array}$} \\
\hline & $A C 1$ & $A C 2$ & $A C 3$ & AC4 & AC5 & AC6 & AN1 & AN2 & AN3 & AN4 & AN5 & AN6 & \\
\hline Sex & $q$ & q & $\hat{\sigma}$ & $\hat{\sigma}$ & $\delta$ & 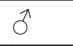 & q & ㅇ & $\pi$ & $\pi$ & $\hat{\sigma}$ & $\hat{\sigma}$ & $q$ \\
\hline Morphology & $A C$ & $A C$ & $A C$ & $A C$ & $A C$ & $A C$ & AN & AN & AN & AN & AN & AN & ND \\
\hline $\operatorname{cox} / \mathrm{PCR}$ & $A C$ & $A C$ & $A C$ & $A C$ & $A C$ & $A C$ & AN & AN & $\begin{array}{l}A N \\
A C^{*}\end{array}$ & AN & AN & AN & ND \\
\hline Alleles AcrCT04 & $\begin{array}{l}123 \\
198\end{array}$ & $\begin{array}{l}135 \\
163\end{array}$ & $\begin{array}{l}123 \\
146\end{array}$ & $\begin{array}{l}135 \\
159\end{array}$ & $\begin{array}{l}135 \\
-\end{array}$ & $\begin{array}{l}135 \\
198\end{array}$ & $\begin{array}{l}109 \\
-\end{array}$ & $\begin{array}{l}109 \\
-\end{array}$ & $\begin{array}{l}109 \\
-\end{array}$ & $\begin{array}{l}109 \\
-\end{array}$ & $\begin{array}{l}109 \\
-\end{array}$ & $\begin{array}{l}109 \\
-\end{array}$ & ND \\
\hline Alleles AcrCA102 & $\begin{array}{l}325 \\
-\end{array}$ & $\begin{array}{l}305 \\
325\end{array}$ & $\begin{array}{l}305 \\
325\end{array}$ & $\begin{array}{l}305 \\
-\end{array}$ & $\begin{array}{l}305 \\
325\end{array}$ & $\begin{array}{l}305 \\
325\end{array}$ & $\begin{array}{l}- \\
-\end{array}$ & $\begin{array}{l}- \\
-\end{array}$ & $\begin{array}{l}- \\
-\end{array}$ & $\begin{array}{l}- \\
-\end{array}$ & $\begin{array}{l}- \\
-\end{array}$ & $\begin{array}{l}- \\
-\end{array}$ & ND \\
\hline
\end{tabular}


Table 2 Results of microsatellite analysis for eggs

\begin{tabular}{|c|c|c|c|c|c|c|c|c|c|c|}
\hline AC + no. 1 & egg 1 & egg 2 & egg 3 & egg 4 & egg 5 & egg 6 & egg 7 & egg 8 & egg 9 & egg 10 \\
\hline $\operatorname{COX} / \mathrm{PCR}$ & $A C$ & $A C$ & $A C$ & $A C$ & $A C$ & $A C$ & $A C$ & $A C$ & $A C$ & $A C$ \\
\hline Alleles AcrCT04 & $\begin{array}{l}123 \\
135\end{array}$ & $\begin{array}{l}146 \\
198\end{array}$ & $\begin{array}{l}123 \\
198\end{array}$ & ND & $\begin{array}{l}123 \\
198\end{array}$ & $\begin{array}{l}123 \\
198\end{array}$ & $\begin{array}{l}123 \\
198\end{array}$ & $\begin{array}{l}135 \\
198\end{array}$ & $\begin{array}{l}198 \\
-\end{array}$ & $\begin{array}{l}123 \\
135\end{array}$ \\
\hline Alleles AcrCA102 & $\begin{array}{l}325 \\
-\end{array}$ & $\begin{array}{l}305 \\
325\end{array}$ & $\begin{array}{l}305 \\
325\end{array}$ & ND & $\begin{array}{l}325 \\
-\end{array}$ & $\begin{array}{l}305 \\
325\end{array}$ & $\begin{array}{l}305 \\
325\end{array}$ & $\begin{array}{l}325 \\
-\end{array}$ & $\begin{array}{l}305 \\
325\end{array}$ & $\begin{array}{l}305 \\
325\end{array}$ \\
\hline potential fathers & $A C 4, A C 5, A C 6$ & AC3 & AC3, AC6 & & AC3, AC6 & $\mathrm{AC3}, \mathrm{AC6}$ & AC3, AC6 & $\mathrm{AC} 4, \mathrm{AC5}, \mathrm{AC6}$ & AC6 & $A C 4, A C 5, A C 6$ \\
\hline AC $q$ no. 2 & egg 1 & egg 2 & egg 3 & egg 4 & egg 5 & egg 6 & egg 7 & egg 8 & egg 9 & egg 10 \\
\hline $\operatorname{cox} / \mathrm{PCR}$ & $A C$ & $A C$ & $A C$ & $A C$ & $\mathrm{AC} / \mathrm{AN}$ & $A C$ & $A C$ & $A C$ & $\mathrm{AC} / \mathrm{AN}$ & $A C$ \\
\hline Alleles AcrCT04 & $\begin{array}{l}163 \\
198\end{array}$ & $\begin{array}{l}135 \\
-\end{array}$ & $C$ & $\begin{array}{l}146 \\
163\end{array}$ & $\begin{array}{l}123 \\
163\end{array}$ & $\begin{array}{l}135 \\
146\end{array}$ & $C$ & $\begin{array}{l}135 \\
159\end{array}$ & $\begin{array}{l}159 \\
163\end{array}$ & ND \\
\hline Alleles AcrCA102 & $\begin{array}{l}325 \\
-\end{array}$ & $\begin{array}{l}305 \\
325\end{array}$ & & $\begin{array}{l}325 \\
- \\
\end{array}$ & $\begin{array}{l}305 \\
325\end{array}$ & $\begin{array}{l}325 \\
- \\
\end{array}$ & & $\begin{array}{l}305 \\
325\end{array}$ & $\begin{array}{l}305 \\
-\end{array}$ & ND \\
\hline potential fathers & AC6 & $\mathrm{AC4}, \mathrm{AC5}, \mathrm{AC6}$ & & $\mathrm{AC3}$ & AC3 & $\mathrm{AC} 3$ & & AC4 & AC4 & \\
\hline AN $q$ no. 1 & egg 1 & egg 2 & egg 3 & egg 4 & egg 5 & egg 6 & egg 7 & egg 8 & egg 9 & egg 10 \\
\hline COx / PCR & AN & AN & AN & AN & AN & AN & AN & AN & AN/AC & AN \\
\hline Alleles AcrCT04 & $\begin{array}{l}109 \\
\mathbf{1 2 3} \\
\end{array}$ & $\begin{array}{l}109 \\
- \\
\end{array}$ & $\begin{array}{l}109 \\
\mathbf{1 4 6} \\
\end{array}$ & $\begin{array}{l}109 \\
123 \\
\end{array}$ & $\begin{array}{l}109 \\
- \\
\end{array}$ & $\begin{array}{l}109 \\
- \\
\end{array}$ & $\begin{array}{l}109 \\
\mathbf{1 3 5} \\
\end{array}$ & $\begin{array}{l}109 \\
- \\
\end{array}$ & ND & $\begin{array}{l}109 \\
\mathbf{1 4 6} \\
\end{array}$ \\
\hline Alleles AcrCA102 & $\begin{array}{l}325 \\
-\end{array}$ & - & $\begin{array}{l}325 \\
-\end{array}$ & $\begin{array}{l}325 \\
-\end{array}$ & - & - & $\begin{array}{l}305 \\
-\end{array}$ & - & ND & $\begin{array}{l}305 \\
-\end{array}$ \\
\hline potential fathers & AC3 & & AC3 & $\mathrm{AC} 3$ & & & $\mathrm{AC4}, \mathrm{AC5}, \mathrm{AC6}$ & & & $\mathrm{AC3}$ \\
\hline AN + no. 2 & egg 1 & egg 2 & egg 3 & egg 4 & egg 5 & egg 6 & egg 7 & egg 8 & egg 9 & egg 10 \\
\hline $\operatorname{cox} / \mathrm{PCR}$ & AN & AN & AN & AN & AN & AN & AN/AC & AN & AN & AN/AC \\
\hline Alleles AcrCT04 & $\begin{array}{l}109 \\
- \\
\end{array}$ & $\begin{array}{l}109 \\
- \\
\end{array}$ & $\begin{array}{l}109 \\
198 \\
\end{array}$ & $\begin{array}{l}109 \\
159 \\
\end{array}$ & $\begin{array}{l}109 \\
- \\
\end{array}$ & $\begin{array}{l}109 \\
198 \\
\end{array}$ & ND & $\begin{array}{l}109 \\
198 \\
\end{array}$ & $\begin{array}{l}109 \\
- \\
\end{array}$ & ND \\
\hline Alleles AcrCA102 & - & - & $\begin{array}{l}305 \\
-\end{array}$ & $\begin{array}{l}305 \\
-\end{array}$ & - & $\begin{array}{l}325 \\
-\end{array}$ & ND & $\begin{array}{l}305 \\
-\end{array}$ & - & $\mathrm{ND}$ \\
\hline potential fathers & & & AC6 & AC4 & & AC6 & & AC6 & & \\
\hline
\end{tabular}

AC: . crassus, AN: A. novaezelandiae; numbers indicate allele size in bp; C: more than 2 alleles were present, indicating contamination with DNA of $2^{\text {nd }}$ individual; alleles indicating hybrids or PCR results showing contaminations are highlighted in bold.

with DNA of another A. crassus individual. The cox $I$ PCR also indicated a weak $A$. novaezelandiae contamination (faint bands) in DNA from eggs no. 5 and no. 9 isolated from AC female no. 2, although no AN alleles were detected in these samples (Table 2). Also, contamination of some DNA samples from $A$. novaezelandiae eggs with A. crassus DNA was detected by cox I-PCR (AN1: egg no. 9, AN2: egg no. 7 and no. 10; see Table 2). These eggs were not taken into account for evaluation of the microsatellite data. Reasons for the contaminations found in one adult nematode (AN3) and several eggs might have been carry over of tissue or eggs from other individuals during sampling or DNA extraction, remainders of sperm in the uteri, or errors during PCR setup. Nevertheless, most individuals were contamination free and allowed reliable interpretation of the results.

These results provide evidence that $A$. crassus and A. novaezelandiae can form hybrids, at least in laboratory infections. As A. crassus originated from Asia and A. novaezelandiae from New Zealand, these species would not have met under natural conditions without human influence. Therefore, evolving a morphological or behavioural reproductive barrier between the two species was not necessary. It is not clear, whether there is some pre- or postzygotic barrier for A. novaezelandiae males to fertilize $A$. crassus females, or if the lack of hybrids from $A$. crassus females was a coincidental result of our study. Further experimental double infections of eels with both Anguillicola spp. will help to answer this question.

Hybridization within different groups of helminth parasites is a well-known phenomenon. In laboratory experiments, hybridization was proven for different Schistosoma spp. [24-27] and two other trematodes, Fasciola hepatica and Fasciola gigantica [28]. In most of these laboratory studies, hybrids showed reduced survival and impaired fertility already in the F1 or F2 generation. However, hybridization among parasites also occurs under natural conditions and was observed in monogeneans [29], schistosomes [30] and nematodes (Anisakis) [31]. The eggs isolated from the females from the present study were fixed in ethanol and therefore it could not be tested, if the hybrid larvae produced are viable, infective, and if they develop into fertile adults, 
but these issues will be investigated in further studies. Therefore, it can only be speculated if hybridization between $A$. crassus and $A$. novaezelandiae is an explanation for what happened in Lake Bracciano.

A case of replacement of one species by another through introgressive hybridization among helminth parasites was described for Schistosoma haematobium and Schistosoma intercalatum in a part of Cameroon where $S$. intercalatum was completely replaced by the introduced $S$. haematobium and the hybrids of both species within about 30 years [32,33]. Laboratory experiments proved that hybrids of $S$. haematobium and $S$. intercalatum were more successful in mating competition than both $S$. intercalatum and, to a lesser extent, S. haematobium [34]. A similar scenario might be possible for Lake Bracciano, though the replacement of A. novaezelandiae by $A$. crassus occurred much faster. But incompatibility of $A$. novaezelandiae males with $A$. crassus females might quickly lead to a dominance of A. crassus genes in the population. The hybrid offspring would also be a selective disadvantage for A. novaezelandiae females, even if these hybrids are not viable. Of course alternative explanations for the disappearance of A. novaezelandiae from Lake Bracciano are likely such as a faster development of larval stages in the copepod intermediate hosts or a broader spectrum of suitable intermediate hosts for A. crassus. These and other lifecycle parameters have to be studied in detail before introgressive hybridization can be figured out as the main reason for the disappearance of $A$. novaezelandiae.

\section{Conclusions}

Results of the present study show that $A$. crassus and A. novaezelandiae might occur in the same host in areas of sympatry like Lake Bracciano. According to our results, hybridization is possible between A. novaezelandiae females and $A$. crassus males, but not vice versa. This finding would fit well to the scenario of Lake Bracciano, where $A$. novaezelandiae seemed to have disappeared. Further laboratory hybridization-experiments are planned to test if this hybrid offspring is viable and fertile, and to analyse their morphology if adult nematodes develop.

\section{Competing interests}

The authors declare that they have no competing interests.

\section{Authors' contributions}

DG was involved in dissecting the nematodes and egg sampling, primer design, molecular work, microsatellite analysis and writing the manuscript. $\mathrm{KD}$ and $\mathrm{BS}$ established and maintained the laboratory life-cycle of nematodes and contributed to writing by corrections and critical comments. KD conducted the infection experiments, eel and nematode dissection and sampling, as well as morphological identification of nematodes and sequencing of cox I. BS had a substantial role in conception of the study and guidance of the practical work. All authors read and approved the manuscript.

\section{Acknowledgements}

This study was supported by DFG via Grant SU217/12-1.

Received: 27 September 2012 Accepted: 29 October 2012 Published: 30 October 2012

\section{References}

1. Moravec F: Dracunculoid and Anguillicoloid Nematodes Parasitic in Vertebrates. Prague: Academia; 2006

2. Laetsch DR, Heitlinger EG, Taraschewski H, Nadler SA, Blaxter ML: The phylogenetics of Anguillicolidae (Nematoda: Anguillicolidea), swimbladder parasites of eels. BMC Evol Biol 2012, 12:60. doi:10.1186/14712148-12-60.

3. De Charleroy D, Grisez L, Thomas K, Belpaire C, Ollevier FP: The life cycle of Anguillicola crassus. Dis Aquat Organ 1990, 8:77-84.

4. Kuwahara A, Itagaki $H$, Itagaki $H$ : Studies of a nematode parasitic in the air bladder of the eel: 1. Description of Anguillicola crassus n. sp. (Philometridae, Anguillicolidae). Jpn J Parasitol 1974, 23:275-279.

5. Kennedy CR: The pathogenic helminth parasites of eels. J Fish Dis 2007, 30:319-334.

6. Kirk RS: The impact of Anguillicola crassus on European eels. Fish Manage Ecol 2003, 10:385-394.

7. Koops H, Hartmann F: Anguillicola-infestations in Germany and in German eel imports. J Appl Ichthyol 1989, 5:41-45.

8. Taraschewski H, Moravec F, Lamah T, Anders K: Distribution and morphology of two helminths recently introduced into European eel populations: Anguillicola crassus (Nematoda, Dracunculoidea) and Paratenuisentis ambiguus (Acanthocephala, Tenuisentidae). Dis Aquat Organ 1987, 3:167-176

9. Knopf K: The swimbladder nematode Anguillicola crassus in the European eel Anguilla anguilla and the Japanese eel Anguilla japonica: differences in susceptibility and immunity between a recently colonized host and the original host. J Helminthol 2006, 80:129-136.

10. Heitlinger EG, Laetsch DR, Weclawski U, Han YS, Taraschewski H: Massive encapsulation of larval Anguillicoloides crassus in the intestinal wall of Japanese eels. Parasit Vectors 2009, 2:48.

11. Egusa S: Notes on the culture of European eel (Anguilla anguilla) in Japanese eel farming ponds. J Conseil Int Explor Mer 1979, 174:51-58.

12. Sures B, Knopf K: Parasites as a threat to freshwater eels? Science 2004 304:208-209.

13. Sures B, Knopf K, Kloas W: Induction of stress by the swimbladder nematode Anguillicola crassus in European eels, Anguilla anguilla, after repeated experimental infection. Parasitology 2001, 123:179-184.

14. Palstra AP, Heppener DFM, van Ginneken VJT, Székely C, van Den Thillart GEE: Swimming performance of silver eels is severely impaired by the swim-bladder parasite Anguillicola crassus. J Ex Mar Biol Ecol 2007, 352:244-256.

15. Moravec F, Taraschewski H: Revision of the genus Anguillicola Yamaguti, 1935 (Nematoda: Anguillicolidae) of the swimbladder of eels, including descriptions of two new species, A. novaezelandiae sp. $n$. and A. papernai sp. n. Folia Parasitol 1988, 35:125-146.

16. Welcomme RL: Register of international transfers of inland fish species. FAO Fish Tech Pap 1981, 213:120.

17. Moravec F, Di Cave D, Orecchia P, Paggi L: Present occurrence of Anguillicola novaezelandiae (Nematoda, Dracunculoidea) in Europe and its development in the intermediate host. Folia Parasitol 1994, 41:203-208.

18. Paggi L, Orecchia P, Minervini R, Mattiucci S: Appearance of Anguillicola australiensis Johnston and Mawson, 1940 (Dracuncoloidea: Anguillicolidae) in Anguilla anguilla of Lake Bracciano. Parassitologia 1982, 24:139-144.

19. Marcel Münderle: Ökologische, morphometrische und genetische Untersuchungen an Populationen des invasiven Schwimmblasen-Nematoden Anguillicola crassus aus Europa und Taiwan. PhD Thesis. University of Karlsruhe, Faculty for Chemistry and Bioscience; 2005.

20. Haenen OLM, Van Wijngaarden TAM, Borgsteede FHM: An improved method for the production of infective third-stage juveniles of Anguillicola crassus. Aquaculture 1994, 123:163-165.

21. Sures B, Knopf $K$ : Individual and combined effects of $C d$ and 3,3/4,4/,5pentachlorobiphenyl (PCB 126) on the humoral immune response in European eel (Anguilla anguilla) experimentally infected with larvae of Anguillicola crassus (Nematoda). Parasitology 2004, 128:445-454. 
22. Knopf K, Würtz J, Sures B, Taraschewski H: Impact of low water temperature on the development of Anguillicola crassus in the final host Anguilla anguilla. Dis Aquat Organ 1998, 33:143-149.

23. Wielgoss S, Sanetra M, Meyer A, Wirth T: Isolation and characterization of short tandem repeats in an invasive swimbladder nematode, parasitic in Atlantic freshwater eels, Anguillicola crassus. Mol Ecol Notes 2007, 7:1051-1053. doi:10.1111/j.1471-8286.2007.01773.x.

24. Fan PC, Lin LH: Hybridization of Schistosoma mansoni and Schistosoma japonicum in mice. Southeast Asian J Trop Med Public Health 2005, 36:89-96.

25. Leroux PL: Hybridization of Schistosoma mansoni and S. rodhaini. Trans Roy Soc Trop Med Hyg 1954, 48:3-4.

26. Taylor MG: Hybridization experiments on five species of African schistosomes. J Helminthol 1970, 44:253-314.

27. Théron A: Hybrids between Schistosoma mansoni and Schistosoma rodhaini: characterization by cercarial emergence rhythms. Parasitology 1989, 99:225-228.

28. Itagaki T, Ichinomiya M, Fukuda K, Fusyuku S, Carmona C: Hybridization experiments indicate incomplete reproductive isolating mechanism between Fasciola hepatica and Fasciola gigantica. Parasitology 2011, 138:'1278-1284. doi:10.1017/S0031182011000965.

29. Barson M, Prikrylová I, Vanhove MPM, Huyse T: Parasite hybridization in African Macrogyrodactylus spp. (Monogenea, Platyhelminthes) signals historical host distribution. Parasitology 2010, 137:1585-1595. doi:10.1017/ S0031182010000302

30. Morgan JAT, DeJong RJ, Lwambo NJS, Mungai BN, Mkoji GM, Loker ES: First report of a natural hybrid between Schistosoma mansoni and S. rodhaini. J Parasitol 2003, 89:416-418.

31. Martín-Sánchez J, Artacho-Reinoso ME, Díaz-Gavilán M, Valero-López A: Structure of Anisakis simplex s.l. populations in a region sympatric for $A$. pegreffii and $A$. simplex s.s. Absence of reproductive isolation between both species. Mol Biochem Parasitol 2005, 141:155-162.

32. Southgate VR, Rollinson D: Interactions of Schistosoma haematobium and S. intercalatum in Loum, Cameroon. In Proceedings of the Third European Multicolloquium of Parasitology: 7-13 September 1980. Cambridge: Cambridge University Press; 1981:24.

33. Tchuem Tchuenté LA, Southgate VR, Njiokou F, Niiné T, Kouemeni LE, Jourdane J: The evolution of schistosomiasis at Loum, Cameroon: replacement of Schistosoma intercalatum by S. haematobium through introgressive hybridization. Trans Roy Soc Trop Med Hyg 1997, 91:664-665.

34. Webster BL, Southgate VR: Mating interactions of Schistosoma haematobium and S. intercalatum with their hybrid offspring. Parasitology 2003, 126:327-338. doi:10.1017/50031182002002883.

doi:10.1186/1756-3305-5-244

Cite this article as: Grabner et al:: Merging species? Evidence for hybridization between the eel parasites Anguillicola crassus and $A$. novaezelandiae (Nematoda, Anguillicolidea). Parasites \& Vectors 2012 5:244.

\section{Submit your next manuscript to BioMed Central and take full advantage of:}

- Convenient online submission

- Thorough peer review

- No space constraints or color figure charges

- Immediate publication on acceptance

- Inclusion in PubMed, CAS, Scopus and Google Scholar

- Research which is freely available for redistribution 